\title{
E-LEARNING BERBASIS MOODLE SEBAGAI MEDIA INFORMASI DAN KOMUNIKASI GUNA MENCEGAH PENYEBARAN COVID-19
}

\author{
Ahmad Fauzi \\ Universitas Islam Jember \\ Abmadfauri.12081989@gmail.com
}

\begin{abstract}
To prevent the spread of Covid-19, various universities and schools began to implement e-learning. This is the application of application-based learning. There are many universities that have organized this learning model program and have passed their students' thesis and dissertation examinations by utilizing this technological sophistication. This paper explains the nature of e-learning model, both its characteristics, strengths, weaknesses and its benefits in preventing the spread of Covid-19. Basically, e-learning has two types, namely synchronous and asynchronous. The Synchronous is learning process all at once between lecturers and students (on line at the same time). Whereas the asynchronous is not at the same time. Students can take different time from lecturers. It can be concluded that e-learning can be used to prevent the spread of covid-19, because there is no face-to-face learning when giving material. E-learning also has several advantages over conventional learning systems. However, e-learning also has shortcomings, such as the lack of interaction between students and teachers even between other students, tend to ignore the social aspects and foster individual aspects, the teaching and learning process tends towards training rather than education, and several other shortcomings.
\end{abstract}

\section{Keywords: E-Learning, Information, Communication, Covid-19}

\begin{abstract}
Abstrak
Guna mencegah penyebaran Covid-19 ini, berbagai Perguruan Tinggi hingga sekolah mulai menerapkan e-learning. Upaya ini adalah penerapan pembelajaran berbasis aplikasi. Ada banyak kampus yang sudah menyelenggarakan program pembelajaran model ini dan sudah meluluskan ujian skripsi, tesis dan disertasi mahasiswanya dengan memanfaatkan kecanggihan teknologi ini. Tulisan ini berupaya untuk menjelaskan hakikat pembelajaran e-learning ini, karakteristik, kelebihan dan kekurangannya serta manfaatnya dalam mencegah penyebaran Covid19. Pada dasarnya, e-learning memiliki dua tipe, yaitu synchronous dan asynchronous. Synchronous artinya proses pembelajaran terjadi pada saat
\end{abstract}


yang sama antara dosen dan mahasiswa (on line di waktu bersamaan). Sedangkan asynchronous tidak pada waktu bersamaan. Mahasiswa dapat mengambil waktu pembelajaran berbeda dengan dosen yang memberikan materi. Dapat disimpulkan bahwa pembelajaran berbasis e-learning dapat dimanfaatkan sebagai media untuk mencegah penyebaran covid-19, sebab tidak dibutuhkan adanya tatap muka dalam pemberian materi pelajaran. E-learning juga memiliki beberapa kelebihan dibandingkan dengan sistem pembelajaran konvensional. Namun demikian, e-learning juga memiliki kekurangan, seperti minimnya interaksi antara pelajar dengan pengajar bahkan antara pelajar yang lain, kecenderungan mengabaikan aspek sosial dan membuat tumbuhnya aspek individual, proses belajar mengajar cenderung ke arah pelatihan dari pada pendidikan, dan beberapa kekurangan lainnya.

\section{Kata Kunci : E-Learning, Informasi, Komunikasi, Covid-19}

\section{Pendahuluan}

Pekan ini virus Covid-19 atau yang sering dikenal dengan virus Corona menjadi trending topic di berbagai kalangan, dari pemerintah pusat sampai komunikasi di warung kopi. Penyebaran virus yang sangat cepat inilah yang menjadi perhatian banyak masyarakat luas bahkan sampai di berbagai penjuru dunia. Tercatat
140 negara di dunia melaporkan temuan kasus virus corona. ${ }^{1}$

Pandemi virus corona mengakibatkan beberapa lembaga pendidikan meliburkan peserta didiknya. Pada akhirnya mereka memanfaatkan fasilitas belajar jarak jauh alias e-learning.

Dengan fasilitas e-learning, libur sekolah/Kuliah bukan berarti tidak belajar, apalagi bagi yang siap-siap menghadapi ujian. Aplikasi ini juga tersedia gratis mau-

${ }^{1}$ Kompas.com, tanggal 18 Maret 2019 


\section{Ahmad Fauzi}

pun berbayar bagi siswa pelajar dari berbagai tingkat pendidikan.

Dengan berkembangnya Teknologi Informasi dan Komunikasi (TIK) yang semakin pesat, kebutuhan akan suatu konsep dan mekanisme belajar mengajar (pendidikan) berbasis TI menjadi konsekuensinya. Konsep yang kemudian terkenal dengan sebutan e-learning ini membawa pengaruh terjadinya proses transformasi pendidikan konvensional ke dalam bentuk digital, baik secara isi (contents) dan sistemnya.

E-learning dalam arti luas bisa mencakup pembelajaran yang dilakukan di media elektronik (internet) baik secara formal maupun informal. E-learning secara formal, misalnya adalah pembelajaran dengan kurikulum, silabus, mata pelajaran dan tes yang telah diatur dan disusun berdasarkan jadwal yang telah disepakati pihak-pihak terkait (pengelola e-learning dan pembelajaran sendiri). Pembelajaran seperti ini biasanya tingkat interaksinya tinggi dan diwajibkan oleh perusahaan pada karyawannya atau pembelajaran jarak jauh yang dikelola oleh universitas dan perusahaan-perusahaan (biasnya perusahaan konsultan) yang memang bergerak di bidang penyedian jasa e-learning untuk umum. E-learning bisa juga dilakukan secara informal dengan interaksi yang lebih sederhana, misalnya melalui sarana mailing list, enewsletter atau website pribadi, organisasi dan perusahaan yang ingin mensosialisasikan jasa, program, pengetahuan atau keterampilan tertentu pada masyarakat luas.

\section{Hasil Dan Pembahasan}

Dampak dari virus corona mendorong perguruan tinggi menghentikan perkuliahan dengan tatap muka serta menggunakan metode jarak jauh. Tentu metode jarak jauh ini harus menggunakan fasilitas teknologi informasi, salah satunya e-learning. E-learning adalah 
An-Nisa' : Jurnal Kajian Perempuan \& Keislaman

Vol. 13, No. 1, April 2020

p-ISSN:2086 -0749

e-ISSN:2654-4784

teknologi informasi dan komunikasi untuk mengaktifkan peserta didik untuk belajar kapanpun dan di manapun.

E-learning adalah suatu sistem atau konsep pendidikan yang memanfaatkan teknologi informasi dalam proses belajar mengajar. Berikut beberapa pengertian $e$ learning dari berbagai sumber: Pertama, menurut Chandrawati, proses pembelajaran jarak jauh dengan menggabungkan prinsip-prinsip dalam proses pembelajaran dengan teknologi; Kedua, menurut Ardiansyah, sistem pembelajaran yang digunakan sebagai sarana untuk proses belajar mengajar yang dilaksanakan tanpa harus bertatap muka secara langsung antara guru dengan siswa; Ketiga, pembelajaran yang disusun dengan tujuan menggunakan sistem elektronik atau komputer se- hingga mampu mendukung proses pembelajaran. $^{2}$

Pengertian e-learning banyak memiliki arti karena bermacam penggunaan e-learning saat ini. Pada dasarnya, e-learning memiliki dua tipe yaitu synchronous dan asynchronous. Synchronous berarti pada waktu yang sama. Proses pembelajaran terjadi pada saat yang sama antara dosen dan mahasiswa. Hal ini memungkinkan interaksi langsung antara pendidik dan peserta didik secara online.

$$
\text { Dalam implementa- }
$$
sinya, synchronous training mengharuskan dosen dan mahasiswa mengakses internet secara bersamaan. Dosen memberikan materi pembelajaran dalam bentuk makalah atau slide presentasi dan mahasiswa dapat mendengarkan presentasi secara langsung melalui

\footnotetext{
2 Allen, Michael, Michael Allen's Guide to E-learning. (Canada : John Wiley \& Sons, 2013), 27.
} 


\section{Ahmad Fauzi}

internet. Mahasiswa juga dapat mengajukan pertanyaan atau komentar secara langsung ataupun melalui chat kepada dosen.

Synchronous

training merupakan gambaran dari kelas nyata, namun bersifat maya (virtual) dan semua peserta didik terhubung melalui internet. Synchronous training sering juga disebut sebagai virtual classroom. Hal ini bisa juga digabungkan dengan live video yang dapat diakses oleh banyak mahasiswa.

Sedangkan asynchronous berarti tidak pada waktu bersamaan. Mahasiswa dapat mengambil waktu pembelajaran berbeda dengan dosen yang memberikan materi. Asynchronous training popular dalam e-learning karena mahasiswa dapat mengakses materi pembelajaran dimanapun dan kapanpun. Mahasiswa dapat melaksanakan pembelajaran dan menyelesaikannya setiap saat sesuai rentang jadwal yang sudah ditentukan. Pembelajaran dapat berbentuk bacaan, animasi, simulasi, permainan edukatif, tes, quis dan pengumpulan tugas.

Aplikasi yang dapat digunakan untuk pembelajaran online ini jenisnya sangat banyak. Misalnya untuk pembelajaran synchronous training dapat menggunakan Zoom, perangkat konferensi video (video call dengan banyak audience). Dosen/pendidik juga dapat menampilkan apa yang ada di layar laptop (screen sharing) kepada mahasiswa. Zoom gratis hanya berdurasi 40 menit dengan maksimal 100 peserta. Selain Zoom, Google Meet dan Webex dapat menjadi pilihan pendidikan dalam menyampaikan materi kepada mahasiswa secara live.

Sedangkan untuk asynchronous training dosen atau pendidikan dapat menggunakan screencastify dan loom. Namun masih banyak aplikasi lainya yang bisa dimanfaatkan oleh pendidik dalam menyampaikan 
Vol. 13, No. 1, April 2020

p-ISSN:2086 -0749

e-ISSN:2654-4784

bahan ajarnya kepada mahasiswa dalam bentuk rekaman. Untuk Melakukan tes, kuis, atau asesmen dosen dapat menggunakan kahoot, quiziza, dan Googleform.

\section{Karakteristik E-Learning}

Karakteristik e-learning bersifat jaringan, yang membuatnya mampu memperbaiki secara cepat, menyimpan atau memunculkan kembali, mendistribusikan, dan sharing pembelajaran dan informasi. Karakteristik e-learning menurut Nursalam adalah:

a. Memanfaatkan jasa teknologi elektronik.

b. Memanfaatkan keunggulan komputer (digital media dan komputer networks)

c. Menggunakan bahan ajar yang bersifat mandiri (self learning materials) kemudian disimpan di komputer, sehingga dapat diakses oleh dosen dan maha- siswa kapan saja dan dimana saja.

d. Memanfaatkan jadwal pembelajaran, kurikulum, hasil kemajuan belajar, dan hal-hal yang berkaitan dengan administrasi pendidikan dapat dilihat setiap saat di komputer. ${ }^{3}$

e. Manfaat dan Kelebihan ELearning

f. Manfaat e-learning menurut Pranoto, dkk adalah: ${ }^{4}$

g. Penggunaan e-learning untuk menunjang pelaksanaan proses belajar dapat meningkatkan daya serap mahasiswa atas materi yang diajarkan.

h. Meningkatkan partisipasi aktif dari mahasiswa.

i. Meningkatkan kemampuan belajar mandiri mahasiswa.

3 Nursalam dan Ferry Efendi. Pendidikan dalam Keperawatan. (Jakarta: Salemba Medika, 2008), 138.

4 Pranoto, Alvini.dkk. Sains dan Teknologi. (Jakarta: PT Gramedia Pustaka Utama. 2009), 309. 


\section{Ahmad Fauzi}

j. Meningkatkan kualitas materi pendidik dan pelatihan.

k. Meningkatkan kemampuan menampilkan informasi dengan perangkat teknologi informasi, dimana dengan perangkat biasa sulit dilakukan.

Dari beberapa manfaat di atas dapat disimpulkan bahwa, pertama, pembelajaran ini sangat Fleksibel. E-learning memberi fleksibilitas dalam memilih waktu dan tempat untuk mengakses materi. Kedua, belajar mandiri. Elearning memberi kesempatan bagi pembelajar secara mandiri memegang kendali atas keberhasilan belajar, dan ketiga, efisiensi biaya. E-learning memberi efisiensi biaya bagi administrasi penyelenggara, efisiensi penyediaan sarana dan fasilitas fisik untuk belajar dan efisiensi biaya bagi pembelajar adalah biaya transportasi dan akomodasi.

Adapun kelebihan Menurut L. Tjokro e-learning sebagai berikut: a. Lebih mudah diserap, artinya menggunakan fasilitas multimedia berupa gambar, teks, animasi, suara dan video.

b. Jauh lebih efektif dalam biaya, artinya tidak perlu instruktur, tidak perlu minimum audiensi, bisa dimana saja, bisa kapan saja, murah untuk diperbanyak.

c. Jauh lebih ringkas, artinya tidak banyak formalitas kelas, langsung pada pokok bahasan, mata pelajaran sesuai kebutuhan.

d. Tersedia 24 jam/hari-7 hari/minggu, artinya penguasaan materi tergantung pada semangat dan daya serap siswa, bisa dimonitor, bisa diuji dengan e-test. ${ }^{5}$

\section{Kekurangan E-Learning}

Selain kelebihan tentu ada pula kekurangan e-learning menurut yang diuraikan oleh Nursalam ${ }^{6}$, sebagai berikut:

\footnotetext{
${ }^{5}$ L. Tjokro, Sutanto. Presentasi yang Mencekam. (Jakarta: Elex Media Komputindo.2009), 187.

${ }^{6}$ Nursalam dan Ferry Efendi. Pendidikan dalam Keperawatan, 140.
} 
a. Kurangnya interaksi antara pengajar dan pelajar atau bahkan antar pelajar itu sendiri.

b. Kecenderungan mengabaikan aspek akademik atau aspek sosial dan sebaliknya membuat tumbuhnya aspek bisnis/komersial.

c. Proses belajar mengajar cenderung ke arah pelatihan daripada pendidikan.

d. Berubahnya peran pengajar dari yang semula menguasai teknik pembelajaran konvensional, kini juga dituntut mengetahui teknik pembelajaran yang menggunakan ICT (information, communication dan technology).

e. Tidak semua tempat tersedia fasilitas internet (mungkin hal ini berkaitan dengan masalah tersedianya listrik, telepon, ataupun komputer). f. Kurangnya sumber daya manusia yang menguasai internet.

g. Kurangnya penguasaan bahasa komputer.

h. Akses pada komputer yang memadai dapat menjadi masalah tersendiri bagi peserta didik.

i. Peserta didik bisa frustasi jika mereka tidak bisa mengakses grafik, gambar, dan video karena peralatan yang tidak memadai.

j. Tersedianya infrastruktur yang bisa dipenuhi.

k. Informasi dapat bervariasi dalam kualitas dan akurasi sehingga penduan dan fitur pertanyaan diperlukan.

1. Peserta didik dapat merasa terisolasi.

Kekurangan e-learning berbasis web menurut Munir sebagai berikut: 


\section{Ahmad Fauzi}

a. Kurangnya interaksi baik antara pengajar dengan pembelajar maupun antara pembelajar satu dengan yang lainnya. Hal ini terjad/i karena dalam pembelajaran berbasis web, kelas dilakukan secara virtual sehingga interaksi yang dilakukan masih kurang.

b. Terkadang lebih terfokus pada aspek teknologi daripada aspek pendidikannya. Produk e-learning merupakan hasil kemajuan teknologi sehingga masih banyak penggunanya yang belum memperhatikan aspek pendidikan yang digunakan di dalamnya. Proses pembelajaran akan terhambat, ketika pengajar tidak mengetahui dan menguasai strategi, metode, dan teknik pembelajaran berbasis teknologi informasi. Sangat diperlukan guru yang memahami kemajuan teknologi saat ini, agar pembelajaran yang dilakukan tetap up to date.

c. Sangat dibutuhkan motivasi dan kemampuan belajar mandiri yang

tinggi dari pembelajar itu sendiri. Keberhasilan e-learning sangat bergantung pada kemauan belajar mandiri dari siswa, sehingga motivasi dari pembelajar juga sangat diutamakan dalam hal ini.

d. Tidak semua pembelajar dapat memanfaatkan semua fasilitas internet. Hal tersebut dikarenakan tidak semua sekolah memiliki fasilitas lengkap yang dapat digunakan siswa untuk mengakses internet.

e. Masih adanya keterbatasan ketersediaan software. Tidak semua software yang digunakan untuk mengembangkan e-learning dapat diperoleh dengan mudah oleh guru.

f. Masih kurangnya pengetahuan dan kemampuan dalam mengoperasionalkan komputer dan internet dengan baik. Hal tersebut dikarenakan terdapat perbedaan kemampuan dan pemahaman siswa maupun guru dalam 
mengoperasikan komputer maupun internet. ${ }^{7}$

Oleh karena itu, pengetahuan dan keterampilan untuk pengembangan bahan belajar elektronik ini perlu dikuasai terlebih dahulu oleh guru/ dosen/instruktur yang akan mengembangkan bahan belajar elektronik. Demikian juga dengan pengelolaan kegiatan pembelajarannya sendiri. Harus ada komitmen dari guru/dosen/ instruktur yang akan memantau perkembangan kegiatan belajar peserta didiknya dan sekaligus secara teratur memotivasi peserta didiknya, kegiatan ini sebenarnya bermuara pada upaya untuk tetap mengendalikan kualitas proses itu sendiri.

3. E-Learning Pencegah Penyebaran Covid-19

7 Munir. Pembelajaran Jarak Jauh Berbasis Teknologi Informasi dan Komunikasi. (Bandung: Alfabeta, 2009), 176-177.
Dari berbagai penjelasan di atas dapat dikatakan bahwa metode e-learning menjadi salah satu sarana untuk mencegah penyebaran virus covid-19. Pendidik maupun dosen dapat menggunakan metode synchronous dan asynchronous beserta berbagai aplikasinya. Tentu hal ini dimaksudkan untuk menghindari kontak langsung antar individu dengan kelompok guna mengurangi persebaran virus covid-19.

Namun yang lebih penting untuk diperhatikan ialah mahasiswa dan siswa, menggunakan masa belajar jarak jauh dengan sebaik mungkin karena walaupun dapat dikatakan libur namun kegiatan belajar harus tetap dilaksanakan, peserta didik dihimbau tidak memanfaatkan waktu belajar di rumah ini untuk bepergian.

Dengan menggunakan bantuan teknologi informasi dan 


\section{Ahmad Fauzi}

komunikasi tersebut. Adanya alatalat itu dapat mengubah pikiran manusia, mengubah cara kerja dan cara hidupnya. Demikian juga, pendidikan tidak terlepas dari pengaruh teknologi. Kejadian ini dapat diidentifikasikan sebagai kemajuan ilmu pengetahuan teknologi, informasi dan komunikasi. ${ }^{8}$

Pengetahuan dan pembelajaran merupakan dua hal yang tidak dapat dipisahkan satu sama lain. Pengetahuan yang didapat oleh seseorang takkan pernah ada bila tanpa melalui proses pembelajaran. Sedangkan hakekat daripada pembelajaran itu sendiri adalah untuk memperoleh pengetahuan. Untuk memperoleh hal-hal tersebut, dapat dilakukan dengan mengikuti pelatihan atau dapat juga dengan membaca buku.

8 Nasution, Teknologi Pendidikan (Jakarta: PT. BumiAksara, 2008), 99.

\section{Simpulan}

Dari uraian di atas, dapat disimpulkan bahwa pembelajaran berbasis e-learning dapat dimanfaatkan sebagai media untuk mencegah penyebaran covid-19. Di samping tidak dibutuhkan adanya tatap muka dalam pemberian materi pelajaran, e-learning memiliki beberapa kelebihan dibandingkan dengan sistem pembelajaran konvensional. Misalnya, materi pelajaran yang lebih mudah diserap karena adanya fasilitas berupa gambar, teks, animasi atau video, jauh lebih efektif dalam biaya karena tidak perlu mengeluarkan banyak uang, materi jauh lebih ringkas karena langsung ke pokok bahasan, dan yang terakhir yaitu tersedia 24 jam dalam 7 hari.

Namun demikian, e-learning juga memiliki kekurangan, seperti minimnya interaksi antara pelajar dengan pengajar bahkan antara pelajar dengan pelajar yang lain, kecenderungan mengabaikan 
aspek sosial dan membuat tumbuhnya aspek individual, proses belajar mengajar cenderung ke arah pelatihan dari pada pendidikan dan berubahnya peran pengajar dari semula yang menguasai teknik pembelajaran konvensional kini dituntut untuk mengetahui teknik pembelajaran yang berinteraksi tanpa bertatap muka secara langsung pada tempat dan waktu yang sama.

\section{Daftar Pustaka}

Allen, Michael. 2013. Michael Allen's Guide to E-learning. Canada: John Wiley \& Sons.

L. Tjokro, Sutanto. 2009. Presentasi yang Mencekam. Jakarta: Elex Media Komputindo.

Munir. 2009. Pembelajaran Jarak Jauh Berbasis Teknologi Informasi dan Komunikasi. Bandung: Alfabeta

Nasution. 2008. Teknologi Pendidikan. Jakarta: PT. BumiAksara.

Nursalam dan Efendi Ferry. 2008. Pendidikan dalam Keperawatan. Jakarta: Salemba Medika.

Pranoto, Alvini, dkk. 2009. Sains dan Teknologi. Jakarta: PT Gramedia Pustaka Utama. 